\title{
Hubert KNOBLAUCH
}

\section{Spirituality and Popular Religion in Europe}

The author develops theoretical and partly tentative arguments on the state of what is called religion with a focus on Europe. The concept of "religion" is complemented by a more basic and less biased notion such as "transcendence", as coined by the phenomenological sociology of Schütz, Berger and Luckmann, a notion that starts from the trajectory of subjective experience and action. In the first part the author focuses on extreme yet quite diverse (western) "religious" movements that are somewhat dynamic, such as marked Christianity and alternative religiosity. Among other sociological features many of these movements lay great stress on subjective experiences of great transcendences (of a large variety of kinds). The actors' notions of spirituality nicely capture this phenomenological feature; moreover, spirituality also covers various sociological aspects, such as the individualistic orientation, the weak tendency to organization and its holistic function, that have also been identified by other researchers. Instead, however, of reducing spirituality to the rather extreme forms of alternative spirituality, the author argues that spirituality of the kind sketched here is disseminated into and communicated by the general culture in such a way as to dissolve the boundaries of religious and non-religious communication. Indeed, modern mediated and popular culture can be identified as a major locus for the distribution of what should be called (modern) "popular religion". It is this form of religion that breaks down the boundaries between "privatized" and "public" religion. It is concluded that the dissolution of the boundaries between the private and public as well as between religiously marked and unmarked communication indicates a basic transformation of religion that demands a reconceptualization in terms of transcendence instead of the binary code sacred/profane.

Keywords: transcendence · phenomenological sociology $\cdot$ subjective experience . religious communication · public and privatized religion · popular religion

L'auteur développe des arguments théoriques et, en partie, expérimentaux à propos de l'état de ce qui est appelé la religion, en se focalisant sur l'Europe. Le concept de "religion" est complété avec une notion plus basique et moins biaisée, celle de la "transcendance", telle qu'elle est pensée par la sociologie phénoménologique de Schütz, Berger et Luckmann, une notion qui prend pour point de départ le parcours de l'expérience subjective et de l'action. Dans la première partie, l'auteur se concentre sur des mouvements "religieux" occidentaux quelque peu extrêmes, mais assez divers et parmi les plus dynamiques, comme la Chrétienté marquée et la religiosité alternative. Entre autres traits sociologiques, un certain nombre de ces mouvements mettent un accent fort sur les

DOI: $10.1177 / 0037768607089735$

http://scp.sagepub.com 
expériences subjectives des grandes transcendances (d'une grande variété de genres). La notion de spiritualité des acteurs rend assez bien ce trait phénoménologique; de plus, la spiritualité couvre aussi des aspects sociologiques variés, tels que l'orientation individualiste, la faible tendance à l'organisation et ses fonctions holistiques, qui ont aussi été identifiées par d'autres chercheurs. Cependant, au lieu de réduire la spiritualité aux formes assez extrêmes de la spiritualité alternative, l'auteur avance que la spiritualité du type esquissé dans l'article est disséminée dans et communiquée par la culture générale, d'une manière telle qu'elle brouille les frontières de la communication religieuse et non-religieuse. En effet, la culture moderne modérée et populaire peut être considérée comme un lieu majeur de diffusion de ce qui devrait être appelé "la religion populaire" (moderne). Celle-ci dépasse les frontières entre "religion publique" et "privée". En guise de conclusion, l'auteur avance que la dissolution des frontières entre public et privé, autant que celle des frontières entre communications religieusement marquée et non marquée, indique une transformation fondamentale de la religion qui requiert une reconceptualisation en terme de transcendance, en lieu et place du code binaire sacré/profane.

Mots-clés: transcendance $\cdot$ sociologie phénoménologique $\cdot$ expérience subjective $\cdot$ communication religieuse $\cdot$ religion publique et privée $\cdot$ religion populaire

\section{Introduction}

In recent years, religion has once again become the focus of public attention. Although one should not consider the increasing media attention paid to religion as tantamount to its increasing importance, there is nevertheless good reason to assume that religion has gained in importance since the end of the Cold War with its competing secular ideologies. ${ }^{1}$ The increase in religion can be discerned worldwide, but with one often explicitly noted exception: Europe has come to be seen almost as an island of disbelief in a sea of religion (Berger, 1999). Yet this view of Europe as a secularized continent appears to me to be exaggerated. It assumes a view of religion that may be useful when looking at Christian and some other institutional forms of religion, but it cannot address the sort of general religious change that also includes Europe. Using a different and more sensitive notion of what actors mean by religion allows one to uncover the religious dynamics that are also occurring in Europe, and in Germany in particular.

I suggest that the notion of transcendence is one that, as I will show, is capable of addressing this kind of dynamic. The idea of transcendence draws on the phenomenological positions of Schütz, Berger and Luckmann. Contrary to what is commonly assumed, Luckmann's well-known notion of transcendence has recently undergone a transformation, and therefore it might be helpful to draw a brief sketch of its relationship to religion. ${ }^{2}$ In this phenomenological sense, religion is subsumed under those forms of experience and action that refer to the great transcendences, ones that go beyond the everyday life-world characterized by pragmatic orientations, intersubjectivity, and 
mundane communication. Transcendences as such are a general feature of the act of experiencing (not of the experienced object) because of their intentionality: as experience of something, experience always refers to something else. This relatedness as an accomplishment of consciousness can be heuristically subdivided into various ranges of reference: whereas little transcendences exceed the immediacy of space and time in that they refer to the past and future, not the experienced present, medium transcendences refer to the experience of alter ego, which is only indirectly accessible through the mediation of signs and communication. Great transcendences, finally, refer to the boundaries of what is taken for granted in everyday social life. ${ }^{3}$ Even if these boundaries vary across cultures, societies typically "domesticate" these experiences of transcendence by defining what is to be taken as "real". The use of the notion of transcendence, however, already indicates that this domestication need not necessarily take the social form of religion. ${ }^{4}$ Indeed, from this perspective, religion in the narrow sense becomes a special form of the domestication of transcendence that probably developed during the last "Axial Age" (as Jaspers called it) (Eisenstadt, 1999).

This article will develop a number of theoretical and somewhat tentative arguments on the state of what is called religion in Europe. It will argue that the tendencies discussed point to the need for the concept of "religion" to be complemented by a more basic and less biased notion such as "transcendence". It focuses first on those (western) "religious" movements that are the most dynamic, such as marked Christianity and alternative religiosity. Among other sociological features, many of these movements lay great stress on subjective experiences of a large variety of great transcendences. The notion of spirituality nicely captures this phenomenological feature; moreover, this notion also covers various sociological aspects, such as individualistic orientation and a weak tendency to organization and its holistic function. Moreover, this kind of spirituality is communicated by the market and the media in such a way that it overlaps the boundaries between religious institutions and popular culture, thereby becoming a "popular religion" that overcomes the boundaries between "privatized" and "public" religion. The conclusion that I draw is that the dissolution of the boundaries between the private and the public, as well as between religiously marked and unmarked communication, points to a basic transformation of religion that demands a reconceptualization in terms of transcendence.

\section{Dynamics of religion in Europe and elsewhere: holistic movements}

In this section, a comparative and admittedly rough overview will focus on those religious movements that appear to be growing and that allow for comparisons, in this case comparisons within the Western tradition.

As a first phenomenon, one cannot ignore what may be loosely summarized as marked Christianity: on a worldwide level, it is quite obvious that 
Christianity is booming. If one looks at those forms of religion that are invigorating religious life, however, these are much less in the religious mainstream and in large organizations. Within the western sphere, the dynamism is associated with "marked" forms of Christianity. By marked (a notion borrowed from linguistics) I mean that this kind of religiosity is highly visible because it uses forms of communication that are recognizably religious. That is to say, they are identified in the social stock of knowledge and the collective memory of the respective societies as religious by anyone who is part of the culture - even those who are secularized and have little knowledge of religion. ${ }^{5}$ Of course, the classical forms of religious organization, such as churches, sects or denominations, are also important ways to "mark" religiosity. Yet, in spite of the clearly marked character of religious organizations and their public presence, communication between these mainstream religious organizations and most of the public in the various spheres is often not clearly marked in religious terms. Even those activities that address religious topics (such as ministry in hospitals) avoid marked religious language.

Certain movements, however, are expressly reclaiming both public and marked religiosity. These movements also have a second notable, if perhaps less visible, feature: they lay great stress on the subjective experience of transcendence. Take for example Pentecostalism and prophetic or charismatic movements. They all stress the importance of an experience of transcendence, such as conversion, glossolalia, prophetic visions, miraculous healing or other "gifts of the spirit". 6 These experiences are not to be had vicariously (not even in many Catholic charismatic movements) through the mediation of religious virtuosi. Rather each person is expected to have, even to have had, such an experience (cf. Stromberg, 1993).

Although the size of these movements is difficult to estimate, there are clear indications that they are quite large. On the world level, there are probably some 200 to 300 million Pentecostals and some 250 to 500 million Charismatics (even Catholic Charismatics may number almost 100 million). These numbers are increasing rapidly. Some predictions see them constituting the majority of Christians within the next decade. ${ }^{7}$ The growth is most rapid outside Europe; within Europe the growth is much more modest. In Germany, for example, by the end of the 1990s, out of a population of 82 million, there were only about 150,000 to 250,000 Charismatics and about 150,000 Pentecostals; and they were increasing only slowly (Kern, 1998).

If one is looking for dynamic expressions of religiosity in Europe and in Germany, then one must also include other forms, especially the series of movements that may be defined as alternative religiosity (Hunt, 2003) or alternative spirituality (Heelas and Woodhead, 2005). One of the features of this kind of religiosity is that the relevant movements (often as a result of globalized communication, tourism and migration) do not draw significantly on the dominant forms of religion in western societies, or at least the cultural memory of European societies recognizes them as different from these dominant forms. Some religious movements, for instance, look 
to Asian religions, to Amerindian shamanic and other "indigenous" religiosities, while Western pagan movements look to Celtic, Germanic, or Norse religions. In this category also fall marginal and "deviant" Christian traditions, such as the "mystical" traditions of Hildegard of Bingen or Meister Eckhart described even in some management and Zeitgeist journals. Alternative spirituality also includes those psychological traditions that refer to the hidden dimensions of the inner self or to the relationship between the inner world and the transcendent world, such as the Human Potential Movement. Alternative religiosity avails itself of a range of bodily techniques, particularly healing techniques, meditation, yoga, Ayurveda and those forms of belief that used to be labelled as "superstition" or folk-belief, forms such as esotericism, occultism and spiritualism (Stollberg and Frank, 2002). One should mention at this point that alternative medicine, for example homeopathy, particularly among non-medical healers or other healing practitioners and non-academic ranks of professional medicine, has strongly contributed to the dissemination of some of the beliefs and practices of alternative religion into the wider population (Antritzky, 1997).

Although attempts to identify alternative religiosity as a distinct movement, for instance as a "New Age" movement or as the "cultic milieu", have thus far been rather unsuccessful (cf. Knoblauch, 1989), a number of surveys do support the idea that elements of the beliefs and practices of alternative religiosity have infused into the contemporary world view of Western societies, for example in Germany. Even though research on church religiosity tends to downplay this development, a large number of Germans and other Europeans affirm belief in elements of alternative religiosities such as astrology, reincarnation or occult energy and powers. ${ }^{8}$ Indeed, reincarnation has become one of the most common beliefs even among church members, and practices of alternative religion, such as meditation, have become widely accepted (Sachau, 1996).

As much as alternative religiosity may differ from marked Christianity and as strongly as the Christian movements discussed may insist on the difference, the two manifestations do nevertheless have a number of features in common. Despite the importance of collective rituals among the Christians, both movements lay strong emphasis on the individual; both tend to avoid large formal organizations; both avail themselves extensively of modern means of communication. ${ }^{9}$ From a phenomenological point of view, one should highlight another common feature: they both lay stress on personal experience of great transcendences. At the core of what people appreciate in alternative religion are experiences that transcend everyday life, whether this be the encounter with spiritual beings in channelling, the vision of the (beautiful New Age) other world in near-death experiences and reincarnation therapy, or "consciousness expansion" through meditation and newly found or reconstructed rituals. Although social surveys on religion rarely account for experiences at all, some indications in social psychology attest to their importance (Argyle, 2000: 46ff). To give another example, in a survey that my colleagues and I conducted on near death experiences, we found that 4.3 per cent of the population in Germany claim to have had 
such an experience (Knoblauch, 2001b). As another example (if one may refer to the seemingly more mundane "paranormal" experiences), Schmied and Deflorin (2000) found that almost 75 per cent of the German population claim to have had one of a number of paranormal experiences that transcend everyday reality. In their telephone interviews, they found that quite a few of the interviewees interpreted these experiences in "religious" terms. Indeed, parapsychology and spiritism cover a wide range of phenomena resembling alternative religious experience, without being necessarily interpreted as religious by researchers and thus escaping almost every survey on religion. And, as cross-cultural comparisons of transcendent experience show (Neitz and Spickard, 1989), what some will see as the miraculous light symbolizing the transcendent Other, others may interpret as an unidentified flying object to be photographed and studied quasi-scientifically. Looking at the range of transcendent experiences, it seems utterly inadequate to assume a clear distinction between those that are religious and those that are not. For example, ecstatic experiences transcending the world of everyday life have become quite common in popular culture, but they are not necessarily interpreted as representing another order beyond the secular. Although they are not necessarily understood as religious, one still has to account for the importance of these experiences, which, as we have seen, also play a crucial role in the dynamic, expressly religious movements. In the process, one has to account for the subjectivity of these experiences.

\section{Spirituality}

The stress laid on subjective transcendent experience may be only one feature of these movements, yet it is a feature that seems to me most important and most often overlooked. These experiences no doubt vary significantly. From a phenomenological perspective, however, they are all experiences of great transcendence. Actors often stress the importance of these experiences in their notion of spirituality, a category that seems to cover almost as broad a range of phenomena as what the actors see as the different and sometimes even opposed notion of religion. Thus, in a survey of 4,000 people in Germany on near-death experiences, only 10 per cent related their experience to Christianity or to religion in general (Knoblauch, 2001b). ${ }^{10}$

Spirituality is thus a subjective notion, but it is also often used as an analytical category by sociological observers of religion. Although the use of the same word seems unavoidable (as any student of "religion" knows), its sociological use requires a more precise definition. A briefly sketched sociological definition of contemporary spirituality therefore follows. ${ }^{11}$ As indicated, spirituality differs from religion by the stress laid on subjective experience of great transcendences by "ordinary" people. Students of Weber (1978) may detect the fundamental change with respect to traditional religion: charisma is not restricted to virtuosi or administered by organizations, but becomes generalized and subjectivized. It is not the dogma but the subjective experience of transcendence by potentially anyone that defines 
what is to be believed. This generalization of charisma combines with other sociological features already highlighted by Troeltsch (1992) in his idea of "mysticism": subjectivity accompanies strong individualization and strong tendencies of de-traditionalization. Both lead to a certain distancing from authority and dogmatism as carried in religious organizations, as well as to opposition to rigid organizational structures. Another feature of spirituality is holism. In sociological terms, this feature means that spiritual experiences are not only considered as transcending the world of everyday life, they also allow the subject to integrate meaningfully various functionally differentiated spheres of life (Beyer, 1997) which otherwise appear "compartmentalized" in contemporary, highly complex societies (Berger, Berger and Kellner, 1973). Under the conditions of contemporary society, holism helps to link various spheres of life: health and work, body and soul, partnership and business. It allows one to compensate for the fragmentation of modern life and its compartmentalization in different functional roles. Religion as such does not accomplish this holism (Beyer, 1997). It is rather the subjective experiences of great transcendence that, by referring beyond everyday life, encompass the various spheres of one's life. Although in each single case these experiences include additional phenomenological elements, the features mentioned account for the success of the movements mentioned above. In the case of marked religiosity, the meaning of the religious is extended into the profane sphere; in alternative religiosity, the boundary between the sacred and the profane is overcome by extraordinary experiences that bestow an encompassing meaning on what one does and what one lives.

The notion of spirituality is not restricted here, it must be stressed, to "alternative spirituality" (Heelas and Woodhead, 2005), that is, to experiences only related to alternative religiosity. In fact, it should not even be restricted to the religious movements mentioned. These movements are arguably only the most visible and extreme forms of spirituality that have become part of popular culture. Spirituality extends far beyond that marked area that is culturally identifiable as religious and thus blurs the boundary between the religious and the non-religious.

As mentioned, subjectivity, individualism and anti-institutionalism are features that Troeltsch had already related to a certain type of religion, mysticism. Mysticsm, Troeltsch argued, is not just another subordinated form of religion. Rather, he considered it to be an autonomous social form of religion equivalent to the church or the sect. As Troeltsch demonstrated in his historical studies, this type has a long history in the West and should not be regarded as new or as "post-modern". Nonetheless, this type would seem to take on special significance under contemporary conditions of intensive differentiation of the social structure of society and the increasing complexity of social knowledge and communication. The subjectivism exhibited in the movements mentioned is an expression of a profound transformation of religion. Before we return to this argument in the conclusion, however, we need to discuss changes in the communication of transcendent meaning that foster the dissemination of spirituality. 


\section{Privatization and popular culture}

The idea that the boundaries of the religious are being redrawn is linked to the transformation of the private sphere which is the result of the recent change in societal communication. The role of religious organizations in public discourse has led to the view that the notion of privatization no longer accounts adequately for the current situation of religion (Casanova, 1994). Although this is certainly true (even if the role that religious organizations play in public communication is not really new), one may doubt that the opposition between "public religion" and privatization still holds. Thus Bauman (1999) argues that the boundaries between the public and the private are being dissolved. The pluralization of mass media communication and the massive expansion of interactive media and digital communication devices have accelerated this process. Each individual is now more or less easily linked to an indeterminate number of other, globally available, individualized actors. These actors do not necessarily constitute an audience or "public" in the "classical" modern sense, but are rather individualized "users" that, at best, constitute more or less formal networks of communication. As a consequence, contents that used to be very private are more and more openly available. Personal biographies, scenes from one's private life and every kind of religious experience and ritual are now being communicated directly from the individual subject to whoever participates in the respective communication channels and on the respective topics. ${ }^{12}$ Thus, not only in the field of religion, but in many other fields, it is becoming more and more apparent that the modern bourgeois opposition between private and public no longer designates distinct communicative spheres. If there still is such a thing as privacy, it is no longer and not exclusively defined by a clear-cut opposition to the public. Rather, it seems to be immersed in and fused with public communication.

There are good reasons to believe that the dissolution of the private/public distinction affects religious communication. We have witnessed an impressive de-differentiation of religious communication in the last decades, often analyzed under the label "popular culture" (cf. Chidester, 2005). Religious symbols and forms of religious communication that belonged predominantly or exclusively to the "sacred" religious sphere have been disseminated into other cultural spheres and used in non-religious cultural contexts, most importantly in popular commercial media and leisure culture. There has been a diffusion of religious codes into popular culture. One may consider the "metaphorization" of religion as one consequence of this transgression of religious communication (Séguy, 1990). In addition to metaphorization, however, religious organizations and movements have been adapting modes and forms of communication used in popular culture, for example in televangelism, religious pop-music and event marketing strategies. The dissolution of the boundaries between public and private and between religious and non-religious communication as well as the growing importance of subjectivity are yielding a new social form that one may call popular religion. ${ }^{13}$ 
Popular religion is not taken here to mean only the presence of religious symbols in pop culture (Greeley, 1989); nor should it be reduced to "media religion" (Hoover, 1988) or "consumer religion" (Possamai, 2005), or mistaken for "religion populaire" (Isambert, 1982). ${ }^{14}$ Popular religion does not refer to the "religiously" marked parts of culture but rather indicates that the de-differentiation of religious communication results in the general availability and symbolic use of what used to be marked as religion as well as formerly marginalized (alternative) forms of religion. Although all these aspects are involved, through the notion of popular religion this article seeks to underline the fact that the boundaries of marked religiosity claimed by the great institutions are being dissolved in two ways: the lay are actively creating religious communication and the communication of religious organizations is going beyond culturally marked religiosity. On the one hand, religious topics are appearing in and adapted to popular cultural forms, that is, forms that are familiar in popular culture. This tendency has been described widely with respect to religious symbols used in popular culture, such as crosses or occultism in rock music. One should not mistake these adaptations for mere ironic "secularizates". Barz (1992), for instance, showed in a German survey that the yin/yang symbol, among others, has as much religious (spiritual) "symbol value" to the young people interviewed as the Christian cross. On the other hand, and more importantly, topics and symbols that have been administered by specialized religious organizations and that used to be part of marked religion have become diffused into the general popular culture. As an example, death - a marked religious topic particularly in Christian collective memory tradition-has been taken over by a new "ars moriendi" that has clearly been created outside those institutions specialized in religion. Thus the aforementioned phenomenon of neardeath experiences has found an enormous audience. It finds expression in an impressive number of subjective experiences (available in many media), and, in Europe at least, has been put on the agenda mainly by actors from outside the religious institutions and distributed via the channels of modern popular mass culture. With respect to death as a "topos" that used to be almost exclusively part of the sacred cosmos (Luckmann, 1991), a new popular arena of discourse has developed that creates and transmits its most relevant meanings. This includes the caring professions, esoteric "thinkers" or pragmatist consultants, private funeral companies and self-help groups, along with their representation on the Internet and in the mass media. It is as if there were a migration of "topoi" and symbols from the sacred cosmos into the worldview of popular culture. It is popular culture, the mass media and the market that seem to carry this world-view; traditional religious institutions no longer play a central role.

\section{From the sacred to the transcendent}

The dissolution of the boundary between private and public communication directly affects religion. It leads to the dissolution of the boundary between 
religiously marked and non-religiously marked communication. Neither tendency excludes the possibility of clearly marked religious communication carried by religious organizations that are accepted as "legitimate" representatives of what is considered religious in the respective society. Taking cognizance of their divergence from other institutional spheres, and the need for communication across these spheres, some religious organizations may tend to articulate and radicalize their interests in "public religion" more strongly. Yet this stress on communication and public presence is not opposed to spirituality. On the contrary, these tendencies are part of the transformation sketched, namely the dissolution of the boundary between private and public as well as between religious and non-religious communication, accompanied by the increasing importance of the subject and her or his experiences, that is, spirituality.

This transformation is not only an empirical tendency; it also affects the very notion of religion. For if we consider religion as somehow defined by the Durkheimian distinction between the sacred (marked rituals, beliefs and religious organizations such as churches) and the profane, the dissolution affects the very notion of religion and turns it into the spiritual. In consequence, spirituality does not even need to be opposed to institutional religion, since it may be said to constitute a social form of religion essentially distinct from the church or sect style of religion. In other words, the remodelling of the religious/non-religious and the private/public distinction in terms of a popular religion that reflects the growing importance of subjective experience (and its communication) is quite consequential: to the degree that (and for the growing number of those for whom) society changes from something that is the Other exceeding the individual to something that can be addressed communicatively, the model of religion as a binary distinction between the sacred and the profane is changing into a non-binary model. If one may consider spirituality as one significant religious expression of this change, the basic model of religiosity emerging is captured in the phenomenological notion of transcendence, characterized by subjectivity, relatedness and difference, without being opposed to immanence. ${ }^{15}$

If we accept this thesis - and admittedly it is only a tentative theoretical idea-the current rise of religiosity and spirituality will not be considered as desecularization, as the return of religion, or as the "resacralization" of society. Instead, it should be understood as a transformation of religion to a form that is adapted to the current form of modernity and accounts for the growing importance of subjectivities and globalized communication about and with the Other. Although these transformations can be witnessed worldwide (cf. Howell, 2005), they may have peculiar consequences for Europe, for it is here that religion has developed one of its most visible and most efficient social forms, namely the European model of the Church and its Church-state relations. Indeed, one may say that Europe is still the continent where religion is most clearly organized in well-defined formal institutions, and spirituality, therefore, becomes here most clearly visible as a social form separate and different from "religion". 16 


\section{NOTES}

1. In a rather exaggerated way, Fukuyama (1992) styles this as the "end of history".

2. This distinction derives from the late Alfred Schütz (1988), but is elaborated in Luckmann's German revised version of The Invisible Religion (1991) which I have argued adds a phenomenological notion of transcendence to his well-known anthropological category of transcending (Knoblauch, 1999).

3. For an extensive analysis of the world of everyday life and its relationship to transcendences, see Schütz and Luckmann (1988).

4. Max Weber (1988 [1920]) made this point in his famous "Zwischenbetrachtung" on the various value spheres competing with and "functionally equivalent" to religion.

5. This even holds for those regions and populations that have received little or no religious socialization, such as East Germany. Cf. Wohlrab-Sahr (this volume). Thus, the chain of memory that Hervieu-Léger (2000) stresses includes social knowledge through which members of a society identify the cultural forms of religion, forms that are socialized, transmitted and thus, in a general sense, communicated and communicative. See Knoblauch (1998; 2001) for an elaboration of the relationship between communication and knowledge as well as the relationship between communication and religion.

6. In one of the few surveys asking for such experiences, Favre and Stolz (2007) found that almost 80 per cent of charismatics, and up to a quarter of scripturally oriented fundamentalists and moderates, reported having had an experience of "baptism in the spirit".

7. Barrett (2000: 25) estimates the number of Pentecostals and Charismatics at 523 million in 2000 . He predicts some 800 million by 2025 . Brouwer et al. (1996: 6) estimate that about two-thirds of the Protestants in Latin America are Pentecostals.

8. Belief in each of astrology, miraculous healing and reincarnation amounts to between 20 and 30 per cent among both church members and non-members. Cf. Pollack (2003).

9. One should mention that these features also hold for what Roy (2002) calls "l'islam mondialisé".

10. This distinction does not apply just to the religious field in Germany. In the United States, for instance, research by Marler and Hadaway (2002) found that 8.3-11.0 per cent (depending on the age cohort) of a 1994 sample considered themselves to be "religious only", while 14.5-22.6 per cent said they were "spiritual only". The distinction between "religion" and "spirituality" is also found in Australia. Cf. Hughes et al. (2004).

11. For a thorough reconstruction of the notion of spirituality, see Bochinger (1994).

12. Cf. Krüger et al. (2005) for one example of a study of internet religion.

13. In this respect, what seems to me to be most important is how the "field" of religious organizations is structured and to what degree certain organizations can lay claim to what is called religion and have the power to define what is outside the field. There is no doubt that the structures of this field not only vary particularly within Europe; the structure seems also to have a strong influence on the societal acceptance of what is marked as religion. Cf. Casanova (2003).

14. The differences among these and cognate concepts are explained in Knoblauch (2000). 
15. For the dissolution of the distinction inherent in the binary religious code cf. also the systems theoretical analysis by Beyer (2006). However, as opposed to Luhmann's view of religion as communication on the basis of the distinction between transcendence and immanence, the Schützian notion of transcendence does not require a binary opposition.

16. This becomes most evident in the various national processes of "churching" Euro-Islam. It is also evident in the fact that many movements that are clearly "religious" in, for example, the United States are denied this status in Europe (cf. scientology in Germany). And it is finally evident if one looks at the mainstream of European sociology of religion, which still takes the churches' definitions of what religion is at face value (including even most of "alternative spiritualities").

\section{REFERENCES}

Andritzky, Walter (1997) Alternative Gesundheitskultur: Eine Bestandaufnahme mit Teilnehmerbefragung. Berlin: VWB.

Argyle, Michael (2000) Psychology and Religion. London and New York: Routledge and Kegan Paul.

Barrett, David B. (2000) "Annual Statistical Table on Global Mission”, International Bulletin of Missionary Research 24: 1ff.

Barz, Heiner (1992) Postmoderne Religion: Die junge Generation in den Alten Bundesländern. Opladen: Leske und Budrich.

Bauman, Zygmunt (1999) In Search of Politics. Stanford, CA: Stanford University Press.

Berger, Peter (1999) "The Desecularization of the World”, in Peter L. Berger (ed.) The Desecularization of the World: Resurgent Religion and World Politics, pp. 1-18. Washington: Eerdmans.

Berger, Peter, Berger, Brigitte L. and Kellner, Hansfried (1973) The Homeless Mind. New York: Random House.

Beyer, Peter (1997) "Religion, Residual Problems, and Functional Differentiation: An Ambiguous Relationship", Soziale Systeme 3: 219-35.

Beyer, Peter (2006) Religions in Global Society. London: Routledge.

Bochinger, Christoph (1994) 'New Age' und moderne Religion: Religionswissenschaftliche Analysen. Gütersloh: Kaiser.

Brouwer, Steve, Gifford, Paul and Rose, Susan D. (1996) Exporting the American Gospel: Global Christian Fundamentalism. New York: Routledge.

Casanova, José (2003) "Beyond European and American Exceptionalism: Towards a Global Perspective", in Grace Davie, Paul Heelas and Linda Woodhead (eds) Predicting Religion: Christian, Secular and Alternative Futures, pp. 17-29. Aldershot: Ashgate.

Casanova, José (1994) Public Religions in the Modern World. Chicago and London: University of Chicago Press.

Chidester, David (2005) Authentic Fakes: Religion and American Popular Culture. Berkeley: University of California Press.

Eisenstadt, Shmuel N. (1999) Fundamentalism, Sectarianism, and Revolution. Cambridge: Cambridge University Press.

Favre, Olivier and Stolz, Jörg (2007) "Die Evangelikalen: Überzeugte Christen in einer zunehmend säkularisierten Welt", in Martin Bauman and Jörg Stolz (eds) Eine Schweiz-viele Religionen, pp.128-44. Bielefeld: Transcript.

Fukuyama, Francis (1992) The End of History and the Last Man. New York: Free Press. 
Greeley, Andrew M. (1989) God in Popular Culture. Allen, TX: Thomas More.

Heelas, Paul, Woodhead, Linda et al. (2005) The Spiritual Revolution: Why Religion is Giving Way to Spirituality. Oxford: Blackwell.

Hervieu-Léger, Danièle (2000) Religion as a Chain of Memory. New Brunswick, NJ: Rutgers University Press.

Hoover, Stewart M. (1988) Mass Media Religion: The Social Sources of the Electronic Church. Newbury Park, CA: Sage.

Howell, Julia D. (2005) "Muslims, the New Age and Marginal Religions in Indonesia", Social Compass 52(4): 473-93.

Hughes, P., Black, A., Bellamy, P. and Kaldor, P. (2004) "Identity and Religion in Contemporary Australia", Australian Religion Studies Review 17: 53-8.

Hunt, Stephen J. (2003) Alternative Religions: A Sociological Introduction. Aldershot: Ashgate.

Isambert, François-André (1982) Le sens du sacré: Fête et religion populaire. Paris: Presses Universitaires de France.

Kern, Thomas (1998) Schwärmer, Träumer und Propheten. Frankfurt/Main: Knecht.

Knoblauch, Hubert (1989) "Das unsichtbare neue Zeitalter: 'New Age', privatisierte Religion und kultische Milieus", Kölner Zeitschrift für Soziologie und Sozialpsychologie 41(3): 504-25.

Knoblauch, Hubert (1998) "Transzendenzerfahrung und symbolische Kommunikation. Die phänomenologisch orientierte Soziologie und die kommunikative Konstruktion der Religion", in Hartmann Tyrell, Volkhard Krech and Hubert Knoblauch (eds) Religion als Kommunikation, pp. 147-86. Würzburg: Ergon.

Knoblauch, Hubert (1999) "Metaphors, Transcendences and Indirect Communication. Alfred Schütz' Phenomenology of the Life-world and the Metaphors of Religion", in Lieven Boeve, Kurt Frayaerts and James Francis (eds) Metaphor and God-Talk, pp. 75-94. Bern: Peter Lang.

Knoblauch, Hubert (2000) "Populäre Religion: Markt, Medien und die Popularisierung der Religion", Zeitschrift für Religionswissenschaft 8: 143-61.

Knoblauch, Hubert (2001) "Communication, Contexts and Culture: A Communicative Constructivist Approach to Intercultural Communication", in Aldo di Luzio, Susanne Günthner, and Franca Orletti (eds) Culture in Communication: Analyses of Intercultural Situations, pp. 3-33. Amsterdam and Philadelphia: John Benjamins.

Knoblauch, Hubert (2001a) "Les expériences du seuil de la mort en Allemagne: la fin d'un déni?", Recherches sociologiques 32(2): 49-64.

Krüger, Oliver (2005) "Discovering the Invisible Internet Methodological Aspects of Searching Religions on the Internet", Online Journal of Religions on the Internet 1.1.

Luckmann, Thomas (1991) Die unsichtbare Religion. Frankfurt/Main: Suhrkamp.

Marler, Penny and Hadaway, Kirk (2002) "Being 'Religious' or Being 'Spiritual' in America: A Zero-sum Proposition?", Journal for the Scientific Study of Religion 41(2): 289-300.

Neitz, Mary Jo and Spickard, Jim (1989) "Steps toward a Sociology of Religious Experience", Sociological Analysis 51(1): 15-33.

Pollack, Detlef (2003) "Religiousness inside and outside the Church in Selected Post-Communist Countries", Social Compass 50(3): 312-34.

Possamai, Adam (2005) Religion and Popular Culture: A Hyper-Real Statement. Brussels: Peter Lang.

Roy, Olivier (2002) L’Islam mondialisé. Paris: Seuil. 
Sachau, Rüdiger (1996) Westliche Reinkarnationsvorstellungen. Gütersloh: Gütersloher Verlagshaus.

Schmied, Ina and Deflorin, Raffaela (2000) "Psychic Experiences in the German Population: Conception and Realization of an Empirical Study", in F. Steinkamp (ed.) Proceedings of the 43rd Annual Convention of the Parapsychological Association, pp. 86-98. New York.

Schütz, Alfred and Luckmann, Thomas (1988) Structures of the Life-World II. Evanston, IL: Northwestern University Press.

Séguy, Jean (1990) "Rationalisation, modernité et avenir de la religion chez Max Weber”, Archives des Sciences Sociales des Religions 69(1):127-38.

Stollberg, Gunnar and Frank, Robert (2002) "Ayurvedic Patients in Germany", Anthropology and Medicine 9: 223-44.

Stromberg, Peter G. (1993) Language and Self-Transformation: A Study of the Christian Conversion Narrative. Cambridge: Cambridge University Press.

Troeltsch, Ernst (1992) The Social Teachings of the Christian Churches. Louisville: Westminster/John Knox.

Weber, Max (1978) Economy and Society. 2 vols. Berkeley: University of California Press.

Weber, Max (1988[1920]) Gesammelte Aufsätze zur Religionssoziologie I. Tübingen: Mohr.

Prof. Dr. Hubert KNOBLAUCH is Professor of Sociology at the Technical University of Berlin. He studied at the Universities of Konstanz and Brighton. He was visiting fellow in various universities before becoming Professor of the Sociology of Religion at the University of Zurich. In 1997, he received the Christa-Hoffmann-Riem Award for Qualitative Social Research. He is a member of the board of various scientific associations and editor of the Zeitschrift für Religionswissenschaft. His most recent books include: Qualitative Religionsforschung: Religionsethnographie in der eigenen Gesellschaft (Ferdinand Schöningh, 2003); Todesnähe: Wissenschaftliche Beiträge zur Erforschung eines außergewöhnlichen Phänomens (Universitätsverlag Konstanz, 1999); Religionssoziologie (De Gruyter, 1999). ADDRESS: Technical University of Berlin, Franklinstrasse 28/29, 10523 Berlin, Germany. [email: Hubert. Knoblauch@tu-berlin.de] 